\begin{tabular}{|c|c|c|}
\hline 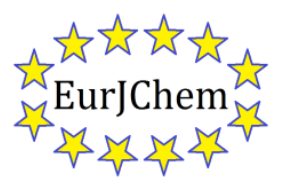 & $\begin{array}{c}\text { European Journal of Chemistry } \\
\text { Journal homepage: } \underline{w w w . e u r j c h e m . c o m ~}\end{array}$ & 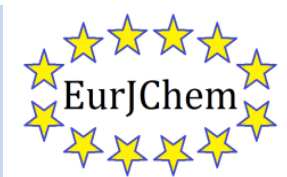 \\
\hline
\end{tabular}

\title{
Synthesis and studying the antitumor activity of novel 5-(2-methylbenzimidazol-5-yl)-1,3,4-oxadiazole-2(3H)-thiones
}

\author{
Shadia A. Galala,*, Ahmed S. Abdelsamiea, Mireya L. Rodriguez ${ }^{\mathrm{b}}$, \\ Sean M. Kerwin ${ }^{b}$ and Hoda I. El Diwania \\ a Department of Chemistry of Natural and Microbial Products, Division of Pharmaceutical and Drug Industries Research, \\ National Research Centre, Dokki, 12622, Cairo, Egypt \\ ${ }^{b}$ Department of Chemistry and Biochemistry, Division of Medicinal Chemistry and Institute for Cellular and Molecular Biology, \\ The University of Texas, Austin, TX 78712 USA
}

${ }^{*}$ Corresponding author at: Department of Chemistry of Natural and Microbial Products, Division of Pharmaceutical and Drug Industries Research, National Research Centre, Dokki, 12311, Cairo, Egypt. Tel.: +202.33371617; fax: +202.3337093. E-mail address: sh12galal@yahoo.com (S. A. Galal).

\section{ARTICLE INFORMATION}

Received: 23 March 2010

Received in revised form: 29 April 2010

Accepted: 30 April 2010

Online: 30 June 2010

\section{KEYWORDS}

\section{Oxadiazoles}

Benzimidazoles

Antitumor activity

Cytotoxicity

Breast cancer human cell (MCF-7)

Lung cancer human cell (A549)

\section{Introduction}

The benzimidazole nucleus is an important pharmacophore in drug discovery due to being a good bioisostere of naturally occurring nucleotides. Several promising antitumor active agents were found to contain the benzimidazole ring system [111]. Benzimidazoles are also used as biomimetics of guanine residues [1] and benzimidazole derivatives selectively inhibit endothelial cell growth and suppress angiogenesis in vitro and in vivo [2]. They were found to exhibit antitumor activity against several tumor cell lines like breast cancer human cell (MCF-7) and lung cancer human cell (A549) [10]. Potent antitumor 2-methylbenzimidazole substituted with 6 or 5membered heterocycles was previously synthesized by our laboratory [12-14]. Compounds I and II were found to be potent against non-small cell lung cancer and breast cancer (Figure 1) [12]. Compounds, 2-methyl-5-nitro-1H-benzo[d] imidazole (III) and 1-(5-)([2-methyl-5-nitro-1 $H$-benzo[ $d]$ imidazol-1-yl)methyl)-1,3,4-thiadiazol-2-ylthio)propan-2-one (IV), were found to have high cytotoxic activity against breast cancer (MCF7) (Figure 1) [14].

On the other hand, five-membered 1,3,4-oxadiazole heterocycles are also useful intermediates for the development of molecules of pharmaceutical interest where several promising antitumor compounds are found to contain the oxadiazole ring system [15-17]. 1,3,4-Oxadiazole heterocycles are good bioisosteres of amides and esters, which can contribute substantially in increasing pharmacological activity by participating in hydrogen bonding interactions with the receptors [18].
As a continuation to our previous work in synthesizing antitumor benzimidazoles, we aimed in this manuscript to investigate the effect of substitution of the benzimidazole moiety at its 5(6) position by a basic moiety, which is 1,3,4oxadiazole carrying different lipophilic and polar groups on the antitumor activity against breast cancer (MCF-7) and lung cancer (A549) human cell lines.

\section{Experimental}

\subsection{Synthesis}

2.1.1. Preparation of 5-(2-methyl-1H-benzo[d]imidazol-5yl)-1,3,4-oxadiazole-2(3H)-thione (7) and 5-(2-methyl-6nitro-1H-benzo[d]imidazole-5-yl)-1,3,4-oxadiazole-2(3H)thione (14)

General Procedure: A mixture of $\mathbf{6 a}$ or $\mathbf{6 b}$ (5 mmole), KOH (5 mmole) and carbon disulphide $(5 \mathrm{~mL})$ in ethanol $(50 \mathrm{~mL})$ was refluxed for $12 \mathrm{~h}$ (Scheme 1). The reaction mixture was then concentrated, cooled and acidified with dilute $\mathrm{HCl}$. The solid mass that separated out, was filtered, washed with ethanol, dried and recrystallized from ethanol as a greenish-brown powder.

2.1.1.1. Compound 7: $R_{\mathrm{f}}=0.76$ (chloroform/ethylacetate/ methanol, 1:2:1). Yield: $90 \%$. M.p.: $>300{ }^{\circ} \mathrm{C}$. ${ }^{1} \mathrm{H}-\mathrm{NMR}(500 \mathrm{MHz}$, DMSO- $\left.\mathrm{d}_{6}\right) \delta: 2.54\left(\mathrm{~s}, 3 \mathrm{H}, \mathrm{CH}_{3}\right), 7.60(\mathrm{~d}, J=8.6 \mathrm{~Hz}, 1 \mathrm{H}, \mathrm{H} 7), 7.65$ (d, $J=8.6 \mathrm{~Hz}, 1 \mathrm{H}, \mathrm{H} 6), 7.92$ (s, 1H, H4), 10.30, 11.63 (br., NH 


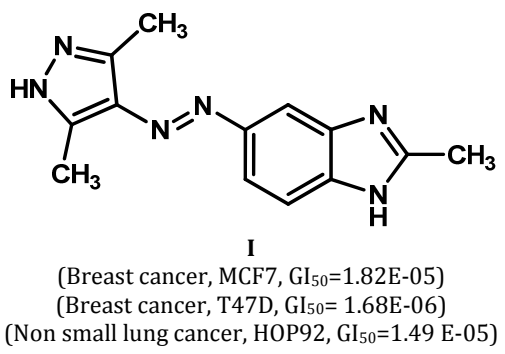

$\mathrm{CH}_{\mathrm{H}}$

(Breast cancer, MCF7, $\mathrm{IC}_{50}=4.2 \mu \mathrm{M}$ )

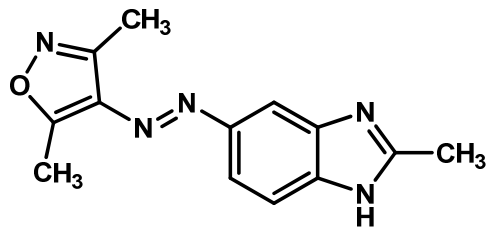

II

(Breast cancer, MCF7, GI50 $=2.87 \mathrm{E}-05$ )

(Breast cancer, T47D, $\mathrm{GI}_{50}=1.68 \mathrm{E}-06$ )

(Non small lung cancer, NCI-H522, GI $\mathrm{G}_{50}=1.25 \mathrm{E}-06$ )

Figure 1. Structures of previously synthesized potent antitumor benzimidazoles.
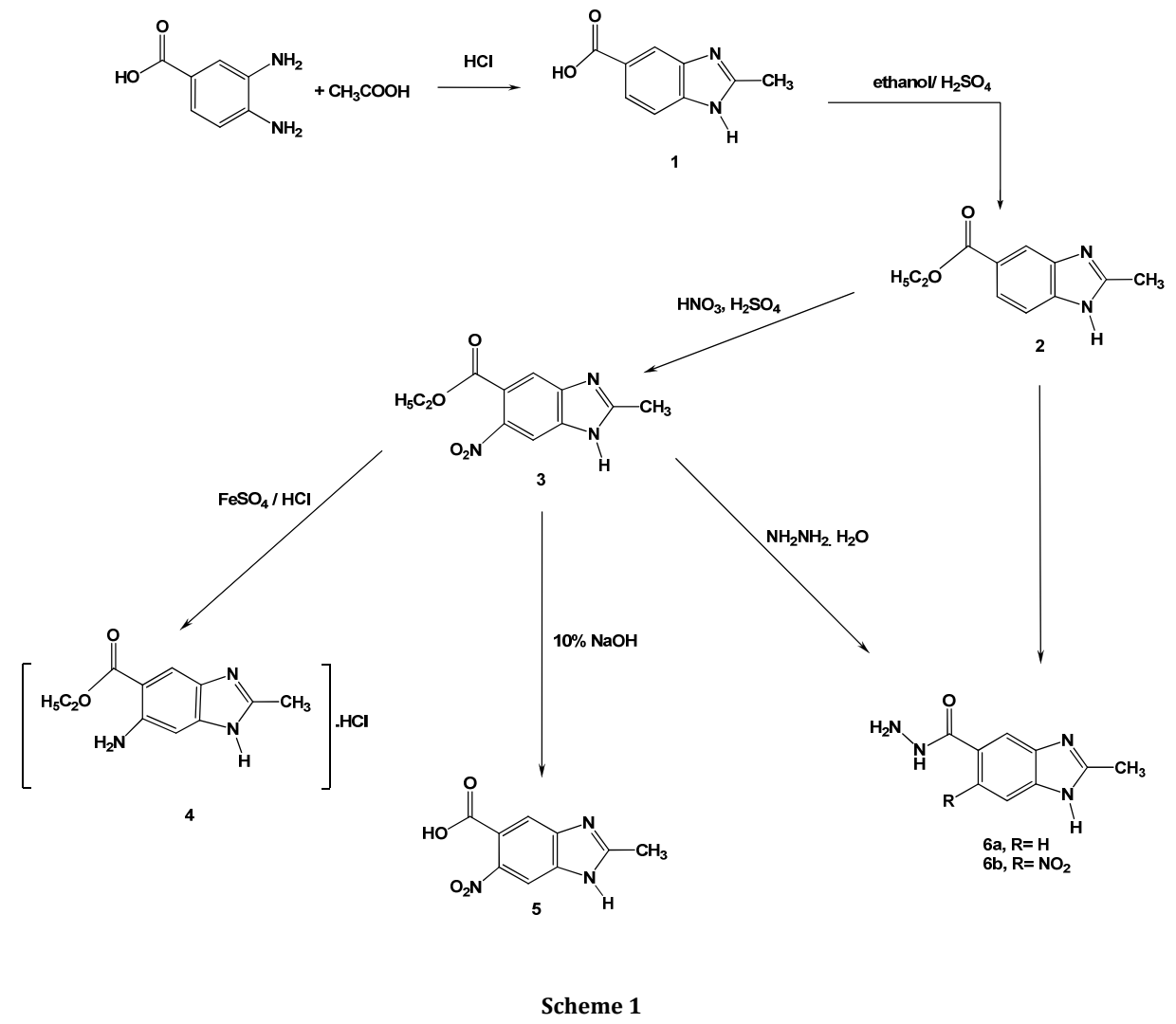

ethanol $/ \mathrm{H}_{2} \mathrm{SO}_{4}$

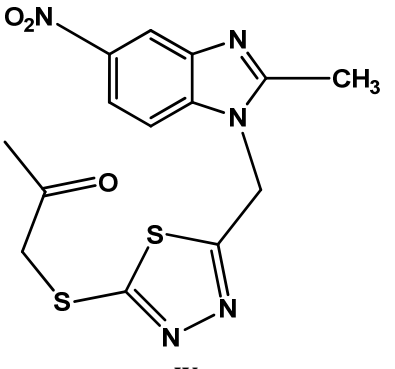

IV

(Breast cancer, MCF7, $\left.\mathrm{IC}_{50}=8.29 \mu \mathrm{M}\right)$

benzimidazole, $\mathrm{NH}$ oxadiazolethione ring, $\mathrm{D}_{2} \mathrm{O}$ exchangeable). IR ( $\left.\mathrm{cm}^{-1}\right): 3406$ ( $\mathrm{NH}$ benzimidazole), $3312(\mathrm{NH}$ oxadiazole ring), 1627 ( $\mathrm{C}=\mathrm{N}$ benzimidazole), 1604 ( $\mathrm{C}=\mathrm{N}$ oxadiazole ring), $1283.55(\mathrm{C}=\mathrm{S})$. MS: $\mathrm{m} / \mathrm{z} 232\left(\mathrm{M}^{+}, 100 \%\right)$. Anal. Calcd for $\mathrm{C}_{10} \mathrm{H}_{8} \mathrm{~N}_{4} \mathrm{OS}$ : C, 51.71; H, 3.47; N, 24.12; S, 13.81. Found: C, 51.59; $\mathrm{H}, 3.36 ; \mathrm{N}, 24.21 ; \mathrm{S}, 13.92$.
2.1.1.2. Compound 14: $R_{\mathrm{f}}=0.73$ (chloroform/ethyl acetate/ methanol, 1:2:1). Yield: 88\%. M.p.: >300 ${ }^{\circ} \mathrm{C} .{ }^{1} \mathrm{H}-\mathrm{NMR}(270 \mathrm{MHz}$, DMSO-d 6 ) $\delta: 2.52\left(\mathrm{~s}, 3 \mathrm{H}, \mathrm{CH}_{3}\right), 7.64(\mathrm{~s}, 1 \mathrm{H}, \mathrm{H} 4), 7.92$ (s, 1H, H7), 9.46 (br., $\mathrm{NH}$ benzimidazole, $\mathrm{D}_{2} \mathrm{O}$ exchangeable). IR $\left(\mathrm{cm}^{-1}\right)$ : 3422 ( $\mathrm{NH}$ benzimidazole), 3312 ( $\mathrm{NH}$ thioxadiazole), $1626(\mathrm{C}=\mathrm{N}$ benzimidazole), 1588 ( $\mathrm{C}=\mathrm{N}$ oxadiazole), 1526 and $1365\left(\mathrm{NO}_{2}\right)$. Anal. Calcd for $\mathrm{C}_{10} \mathrm{H}_{7} \mathrm{~N}_{5} \mathrm{O}_{3} \mathrm{~S}$ : C, 43.32; H, 2.54; N, 25.26; S, 11.56. Found: C, 43.29; H, 2.63; N, 25.16; S, 11.50 . 
2.1.2. Preparation of S-5-(2-methyl-1H-benzo[d]imidazol-5yl)-1,3,4-oxadiazole-2-ylmethanesulfonothioate (8) and S-5(2-methyl-1H-benzo[d]imidazol-5-yl)-1,3,4-oxadiazol-2-yl 2nitrobenzenesulfonothioate (9)

General Procedure: To a solution of 7 (3 mmole) in pyridine $(10 \mathrm{~mL})$ was added methanesulfonyl chloride or 2-nitro benzenesulfonyl chloride ( 4 mmole) and the solution was stirred at room temperature for $12 \mathrm{~h}$ (Scheme 2). The reaction mixture was poured into water and the precipitate formed was filtered off and crystallized from methanol to give $\mathbf{8}$ and $\mathbf{9}$, respectively.

2.1.2.1. Compound 8: Brown solid. $R_{\mathrm{f}}=0.43$ (petroleum ether: ethyl acetate: methanol, 1:2:1/2). Yield: 70\%. M.p.: 125-127 ${ }^{\circ}$ C. ${ }_{1}^{1} \mathrm{H}-\mathrm{NMR} \quad(270 \mathrm{MHz}$, DMSO-d 6$) \quad \delta: 2.44\left(\mathrm{~s}, 3 \mathrm{H}, \mathrm{CH}_{3}\right.$ benz imidazole), $2.82\left(\mathrm{~s}, 3 \mathrm{H}, \mathrm{CH}_{3}, \mathrm{SO}_{2} \mathrm{CH}_{3}\right), 7.48(\mathrm{~d}, J=8.58 \mathrm{~Hz}, 1 \mathrm{H}$, H7), 7.86 (d, $J=8.58 \mathrm{~Hz}, 1 \mathrm{H}, \mathrm{H} 6), 8.40$ (s, 1H, H4), 12.5 (br., NH and $\mathrm{OH}, \mathrm{D}_{2} \mathrm{O}$ exchangeable). IR $\left(\mathrm{cm}^{-1}\right): 3410(\mathrm{NH}), 1628(\mathrm{C}=\mathrm{N}$ benzimidazole), 1604 ( $\mathrm{C}=\mathrm{N}$ oxadiazole ring), $1194\left(\mathrm{SO}_{2}\right)$. Anal. Calcd. for $\mathrm{C}_{11} \mathrm{H}_{10} \mathrm{~N}_{4} \mathrm{O}_{3} \mathrm{~S}_{2}$ : C, 42.57; H, 3.25; N, 18.05; S, 20.66 . Found: C, 42.60; H, 3.21; N, 18.29; S, 20.40

2.1.2.2. Compound 9: Brown solid. $R_{\mathrm{f}}=0.45$ (petroleum ether: ethyl acetate: methanol, 1:2:1/2). Yield: 69\%. M.p.: 213-215 ${ }^{\circ} \mathrm{C}$. ${ }^{1} \mathrm{H}-\mathrm{NMR} \quad(270 \mathrm{MHz}$, DMSO-d 6$) \quad \delta: 2.59\left(\mathrm{~s}, 3 \mathrm{H}, \mathrm{CH}_{3}\right.$ benz imidazole), 7.46 (d, $J=8.58 \mathrm{~Hz}, 1 \mathrm{H}, \mathrm{H} 7), 7.64(\mathrm{~m}, 1 \mathrm{H}, \mathrm{H} 4$ nitrobenzenesulfonothioate), $7.91(\mathrm{~d}, J=8.58 \mathrm{~Hz}, 1 \mathrm{H}, \mathrm{H6}), 8.25$ (m, 2H, H5 ' and $\mathrm{H}^{`}{ }^{\prime}$ nitrobenzenesulfonothioate), $8.44(\mathrm{~s}, 1 \mathrm{H}$, $\mathrm{H} 4), 8.72\left(\mathrm{~m}, 1 \mathrm{H}, \mathrm{H} 3{ }^{`}\right.$ nitrobenzenesulfonothioate), 12.8 (br., $\mathrm{NH}$ and $\mathrm{OH}, \mathrm{D}_{2} \mathrm{O}$ exchangeable). IR $\left(\mathrm{cm}^{-1}\right): 3406(\mathrm{NH}), 1627$ ( $\mathrm{C}=\mathrm{N}$ benzimidazole), 1595 ( $\mathrm{C}=\mathrm{N}$ oxadiazole ring), $1398\left(\mathrm{SO}_{2}\right)$, 1453 and $1368\left(\mathrm{NO}_{2}\right)$. Anal. Calcd for $\mathrm{C}_{16} \mathrm{H}_{11} \mathrm{~N}_{5} \mathrm{O}_{5} \mathrm{~S}_{2}: \mathrm{C}, 46.04 ; \mathrm{H}$, 2.66; N, 16.78; S, 15.36. Found: C, 46.15; H, 2.70; N, 16.70; S, 15.25 .

2.1.3. Preparation of 2-(5-(2-methyl-1H-benzo[d]imidazol-5yl)-1,3,4-oxadiazol-2-ylthio)acetonitrile (10) and 2-((1Hbenzo[d]imidazol-2-yl)methylthio)-5-(2-methyl-1Hbenzo[d]imidazol-5-yl)-1,3,4-oxadiazole(11)

General Procedure: A mixture of $\mathbf{7}$ (5 mmole), chloroacetonitrile or 2-chloromethylbenzimidazole (5 mmole) and anhydrous potassium carbonate $(6 \mathrm{mmole})$ in absolute ethanol $(30 \mathrm{~mL})$ was stirred at room temperature for 6-8 $\mathrm{h}$ (Scheme 3). The mixture was filtered and the filtrate was evaporated until dryness, the residue obtained was washed with water and recrystallized from ethanol to give $\mathbf{1 0}$ and $\mathbf{1 1}$ respectively.

2.1.3.1. Compound 10: Buff solid. $R_{\mathrm{f}}=0.68$ (petroleum ether: ethyl acetate: methanol, 1:2:1/2). Yield: 84\%. M.p.: 228-230 ${ }^{\circ} \mathrm{C}$. ${ }^{1} \mathrm{H}-\mathrm{NMR}\left(270 \mathrm{MHz}, \mathrm{DMSO}-\mathrm{d}_{6}\right) \delta: 2.49\left(\mathrm{~s}, 3 \mathrm{H}, \mathrm{CH}_{3}\right), 4.52(\mathrm{~s}, 2 \mathrm{H}$, $\mathrm{CH}_{2}$ ), $7.63(\mathrm{~d}, J=8.41 \mathrm{~Hz}, 1 \mathrm{H}, \mathrm{H} 7), 7.77$ (d, $J=8.41 \mathrm{~Hz}, 1 \mathrm{H}, \mathrm{H} 6$ ), $8.06(\mathrm{~s}, 1 \mathrm{H}, \mathrm{H} 4), 12.65$ (br., $\mathrm{D}_{2} \mathrm{O}$ exchangeable, $\mathrm{NH}$ benzimidazole). IR $\left(\mathrm{cm}^{-1}\right): 3365(\mathrm{NH}), 2249(\mathrm{C} \equiv \mathrm{N}), 1627(\mathrm{C}=\mathrm{N}$ benzimidazole), 1576 ( $\mathrm{C}=\mathrm{N}$ oxadiazole ring). MS: $\mathrm{m} / \mathrm{z} 271\left(\mathrm{M}^{+}\right.$, $50 \%$ ). Anal. Calcd for $\mathrm{C}_{12} \mathrm{H}_{9} \mathrm{~N}_{5} \mathrm{OS}$ : C, 53.13; H, 3.34; N, 25.81; S, 11.82. Found: C, 53.41; H, 3.20; N, 25.90; S, 11.92 .

2.1.3.2. Compound 11: Brown solid. $R_{\mathrm{f}}=0.36$ (petroleum ether: ethyl acetate: methanol, 1:2:1/2). Yield: 88\%. M.p.: 250-251 ${ }^{\circ} \mathrm{C}$. ${ }^{1} \mathrm{H}-\mathrm{NMR}\left(270 \mathrm{MHz}, \mathrm{DMSO}-\mathrm{d}_{6}\right) \delta: 2.5\left(\mathrm{~s}, 3 \mathrm{H}, \mathrm{CH}_{3}\right), 4.69(\mathrm{~s}, 2 \mathrm{H}$, $\left.\mathrm{CH}_{2}\right), 7.26\left(\mathrm{~m}, 3 \mathrm{H}, \mathrm{H} 5^{`}+\mathrm{H6}^{`}+\mathrm{H} 7^{\prime}\right), 7.51\left(\mathrm{~m}, 1 \mathrm{H}, \mathrm{H} 4{ }^{`}\right), 7.73$ (d, J $=8.35 \mathrm{~Hz}, 1 \mathrm{H}, \mathrm{H} 7), 7.82(\mathrm{~d}, J=8.35 \mathrm{~Hz}, 1 \mathrm{H}, \mathrm{H} 6), 8.26(\mathrm{~s}, 1 \mathrm{H}, \mathrm{H} 4)$, $11.92\left(\mathrm{~s}, 1 \mathrm{H}, \mathrm{NH}, \mathrm{D}_{2} \mathrm{O}\right.$ exchangeable), 12.19 (s, 1H, NH, $\mathrm{D}_{2} \mathrm{O}$ exchangeable). IR $\left(\mathrm{cm}^{-1}\right): 3437(\mathrm{NH}), 1626(\mathrm{C}=\mathrm{N})$. Anal. Calcd for $\mathrm{C}_{18} \mathrm{H}_{14} \mathrm{~N}_{6} \mathrm{OS}$ : C, 59.65; H, 3.89; N, 23.19; S, 8.85. Found: C, 59.72; H, 3.71; N, 23.15; S, 8.95 .
2.1.4. Preparation of 1,2-Bis(5-(2-methyl-1Hbenzo[d]imidazol-5-yl]-1,3,4-oxadiazol-2-ylthio)ethane (12) and Bis(5-(2-methyl-1H-benzo[d]imidazol-5-yl)-1,3,4oxadiazol-2-ylthio)methane (13)

General procedure: A mixture of 7 (5 mmole), dibromoethane or diiodomethane (2.5 mmole) and anhydrous potassium carbonate $(6 \mathrm{mmole})$ in dimethylformamide $(30 \mathrm{~mL})$ was stirred at room temperature for $4 \mathrm{~h}$. The reaction mixture was filtered off and crystallized from ethanol to give $\mathbf{1 2}$ and 13, respectively (Scheme 3).

2.1.4.1. Compound 12: Brown solid. $R_{\mathrm{f}}=0.76$ (petroleum ether: ethyl acetate: methanol, 2:2:1/2). Yield: 76\%. M.p.: 275-277 ${ }^{\circ} \mathrm{C}$. ${ }^{1} \mathrm{H}-\mathrm{NMR}\left(270 \mathrm{MHz}, \mathrm{DMSO}-\mathrm{d}_{6}\right) \delta: 2.50\left(\mathrm{~s}, 6 \mathrm{H}, 2 \mathrm{CH}_{3}\right), 2.77(\mathrm{~s}, 4 \mathrm{H}$, $\left.2 \mathrm{CH}_{2}\right), 7.52\left(\mathrm{~d}, J=8.1 \mathrm{~Hz}, 2 \mathrm{H}, \mathrm{H} 7\right.$ and $\left.\mathrm{H}^{\prime}\right), 7.67(\mathrm{~d}, J=8.1 \mathrm{~Hz}$, 2H, $\mathrm{H} 6$ and $\mathrm{H}^{\prime}$ ), 7.94 (s, 2H, $\mathrm{H} 4$ and $\mathrm{H}^{\prime}$ ), 11.75 (br., NH benzimidazole, $\mathrm{D}_{2} \mathrm{O}$ exchangeable). IR $\left(\mathrm{cm}^{-1}\right): 3359(\mathrm{NH}), 1625$ $(\mathrm{C}=\mathrm{N})$. MS: $\mathrm{m} / \mathrm{z} 490\left(\mathrm{M}^{+}, 3 \%\right)$. Anal. Calcd for $\mathrm{C}_{22} \mathrm{H}_{18} \mathrm{~N}_{8} \mathrm{O}_{2} \mathrm{~S}_{2}$ : C, 53.86; H, 3.70; N, 22.84; S, 13.07. Found: C, 53.70; H, 3.65; N, $22.98 ; \mathrm{S}, 13.16$

2.1.4.2. Compound 13: Brown solid. $R_{\mathrm{f}}=0.75$ (petroleum ether: ethyl acetate: methanol, 2:2:1/2). Yield: 72\%. M.p.: 245-247 ${ }^{\circ} \mathrm{C}$. ${ }^{1} \mathrm{H}-\mathrm{NMR}\left(500 \mathrm{MHz}, \mathrm{DMSO}-\mathrm{d}_{6}\right) \delta: 2.45\left(\mathrm{~s}, 6 \mathrm{H}, 2 \mathrm{CH}_{3}\right), 3.31(\mathrm{~s}, 2 \mathrm{H}$, $\left.\mathrm{CH}_{2}\right), 7.38(\mathrm{~d}, J=8.05 \mathrm{~Hz}, 2 \mathrm{H}, \mathrm{H} 7$ and H7'), $7.59(\mathrm{~d}, J=8.05 \mathrm{~Hz}$, 2H, $\mathrm{H6}$ and $\left.\mathrm{H6}^{\prime}\right), 7.91$ (s, 2H, H4 and H4) ). IR ( $\left.\mathrm{cm}^{-1}\right): 3406(\mathrm{NH})$, $1629(\mathrm{C}=\mathrm{N})$. MS: $\mathrm{m} / \mathrm{z} 478\left(\mathrm{M}^{+}+2,3 \%\right)$. Anal. Calcd for $\mathrm{C}_{21} \mathrm{H}_{16} \mathrm{~N}_{8} \mathrm{O}_{2} \mathrm{~S}_{2}$ : C, 52.93; $\mathrm{H}, 3.38 ; \mathrm{N}, 23.51 ; \mathrm{S}, 13.46$. Found: $\mathrm{C}$, $53.90 ; \mathrm{H}, 3.50 ; \mathrm{N}, 23.60 ; \mathrm{S}, 13.49$.

\subsubsection{Preparation of 2-(5-(2-methyl-6-nitro-1H-} benzimidazole-5-yl)-1,3,4-oxadiazole-2-ylthio)acetonitrile (15)

A mixture of 14 (5 mmole), chloroacetonitrile (5 mmole) and anhydrous potassium carbonate ( $6 \mathrm{mmole}$ ) in absolute ethanol $(30 \mathrm{~mL})$ was stirred at room temperature for $6 \mathrm{~h}$. The reaction mixture was filtered and the filtrate was evaporated until dryness. The residue was washed with water and recrystallized from ethanol as a brown powder (Scheme 4). $R_{\mathrm{f}}=0.66$ (petroleum ether/ethyl acetate/methanol, 1:2:1/4). Yield: 80\%. M.p.: $100-101^{\circ} \mathrm{C}$. IR $\left(\mathrm{cm}^{-1}\right)$ : $3364(\mathrm{NH}), 2250(\mathrm{C} \equiv \mathrm{N}), 1627(\mathrm{C}=\mathrm{N})$, 1577 and $1462\left(\mathrm{NO}_{2}\right), \mathrm{MS}: \mathrm{m} / \mathrm{z} 316\left(\mathrm{M}^{+}, 5 \%\right)$. Anal. Calcd for $\mathrm{C}_{12} \mathrm{H}_{8} \mathrm{~N}_{6} \mathrm{O}_{3} \mathrm{~S}: \mathrm{C}, 45.57 ; \mathrm{H}, 2.55 ; \mathrm{N}, 26.57 ; \mathrm{S}, 10.14$. Found: $\mathrm{C}$, $45.72 ; \mathrm{H}, 2.61 ; \mathrm{N}, 26.40 ; \mathrm{S}, 10.03$.

2.1.6. Preparation of 3-(2-hydroxyphenyl)-2-(5-(2-methyl-6nitro-1H-benzo[d]imidazol-5-yl)-1,3,4-oxadiazol-2. ylthio)acrylonitrile (16) and 2-Imino-3-(5-(2-methyl-6-nitro1H-benzo[d]imidazol-5-yl)-1,3,4-oxadiazol-2-ylthio)-2Hchromen-7-ol (17)

General Procedure: To a solution of 15 (3 mmole) in pyridine $(10 \mathrm{~mL})$ was added an equivalent amount of salicylaldehyde or 2,4-dihydroxybenzaldehyde. The solution was stirred at room temperature for $12 \mathrm{~h}$. The reaction mixture was poured into water and the precipitate formed was filtered off and recrystallised from butanol to give $\mathbf{1 6}$ and $\mathbf{1 7}$, respectively (Scheme 4).

2.1.6.1. Compound 16: Yellowish-green solid. $R_{\mathrm{f}}=0.75$ (petroleum ether: ethyl acetate, 1:1). Yield: $76 \%$. M.p.: 173$175^{\circ} \mathrm{C} .{ }^{1} \mathrm{H}-\mathrm{NMR}\left(270 \mathrm{MHz}, \mathrm{DMSO}-\mathrm{d}_{6}\right) \delta: 2.52\left(\mathrm{~s}, 3 \mathrm{H}, \mathrm{CH}_{3}\right), 6.60$ $(\mathrm{s}, 1 \mathrm{H}, \mathrm{CH}=), 6.84-6.88(\mathrm{~m}, 4 \mathrm{H}$, Phenyl protons $), 7.64(\mathrm{~s}, 1 \mathrm{H}$, $\mathrm{H} 4)$ 


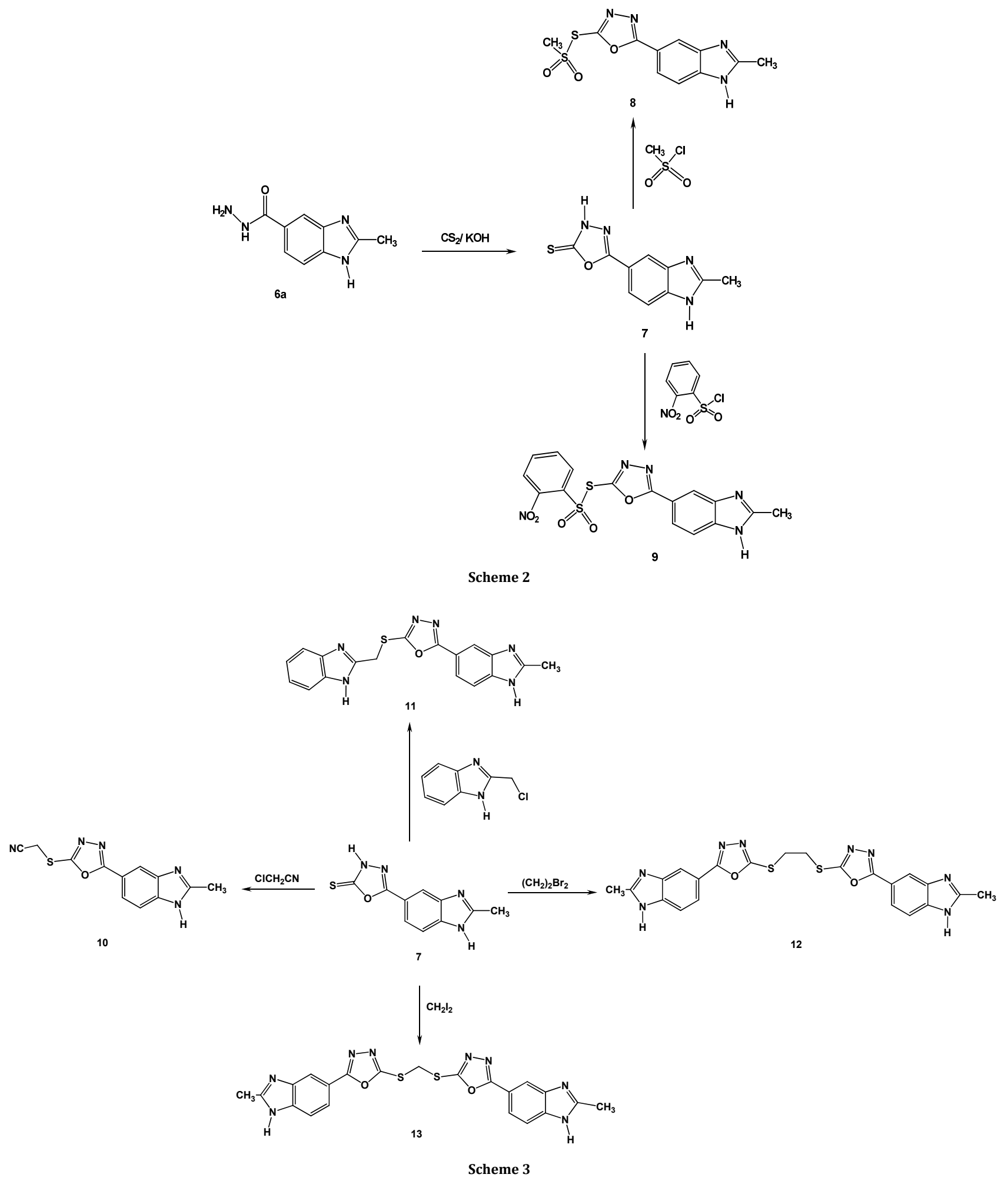

8.05 (s, 1H, H7), 9.46 (br., $\mathrm{NH}$ benzimidazole, $\mathrm{D}_{2} \mathrm{O}$ exchangeable), $11.05(\mathrm{~s}, 1 \mathrm{H}$, phenolic $\mathrm{OH})$. IR $\left(\mathrm{cm}^{-1}\right): 3430(\mathrm{NH}$ benzimidazole), 3000 (br., intermolecular H-bonded $\mathrm{OH}$ ), 2188 $(\mathrm{C}$ ) N ), $1633(\mathrm{C}=\mathrm{N}), 1591$ (C=N oxadiazole), 1527 and 1336 $\left(\mathrm{NO}_{2}\right)$. Anal. Calcd for $\mathrm{C}_{19} \mathrm{H}_{12} \mathrm{~N}_{6} \mathrm{O}_{4} \mathrm{~S}: \mathrm{C}, 54.28 ; \mathrm{H}, 2.88 ; \mathrm{N}, 19.99 ; \mathrm{S}$, 7.63. Found: C, 54.40; H, 2.68; N, 19.77; S, 7.41.

2.1.6.2. Compound 17: White-greenish solid. $R_{\mathrm{f}}=0.16$ (petroleum ether: ethyl acetate, 1:2). Yield: 80\%. M.p.: 130-132 ${ }^{\circ}$ C. ${ }^{1} \mathrm{H}-\mathrm{NMR}\left(270 \mathrm{MHz}, \mathrm{DMSO}-\mathrm{d}_{6}\right) \delta: 2.57\left(\mathrm{~s}, 3 \mathrm{H}, \mathrm{CH}_{3}\right), 6.28(\mathrm{~s}, 1 \mathrm{H}$, H4) 6.35 (d, $J=8.25 \mathrm{~Hz}, 1 \mathrm{H}, \mathrm{H}^{\prime}$ ), 7.10 (br., $1 \mathrm{H}, \mathrm{NH}$ imine, $\mathrm{D}_{2} \mathrm{O}$ exchangeable)), 7.49 (d, $\left.J=8.25 \mathrm{~Hz}, 1 \mathrm{H}, \mathrm{H} 6{ }^{\prime}\right), 8.02(\mathrm{~s}, 1 \mathrm{H}, \mathrm{H} 4)$, $8.18(\mathrm{~s}, 1 \mathrm{H}, \mathrm{H} 8)$ ) 8.40 (s,1H, H7), 8.90 (br., NH benzimidazole, $\mathrm{D}_{2} \mathrm{O}$ exchangeable), $9.87\left(\mathrm{~s}, 1 \mathrm{H}\right.$, phenolic $\mathrm{OH}, \mathrm{D}_{2} \mathrm{O}$ exchange able). IR ( $\left.\mathrm{cm}^{-1}\right): 3433$ ( $\mathrm{NH}$ benzimidazole), 3354 (NH imino), 3000 (br., intermolecular H-bonded OH,), 1629 (C=N), 1529 and $1343\left(\mathrm{NO}_{2}\right)$. Anal. Calcd for $\mathrm{C}_{19} \mathrm{H}_{12} \mathrm{~N}_{6} \mathrm{O}_{5} \mathrm{~S}: \mathrm{C}, 52.29 ; \mathrm{H}, 2.77$; N, 19.26; S, 7.35. Found: C, 52.13; H, 2.81; N, 19.18; S, 7.34.

\subsection{Cytotoxicity Assays}

Cell culture cytotoxicity assays were carried out as described previously [10]. Briefly, aliquots of $100 \mu \mathrm{l}$ cell suspension (1-3 $\times 10^{3}$ cells) were placed in microtiter plates in 


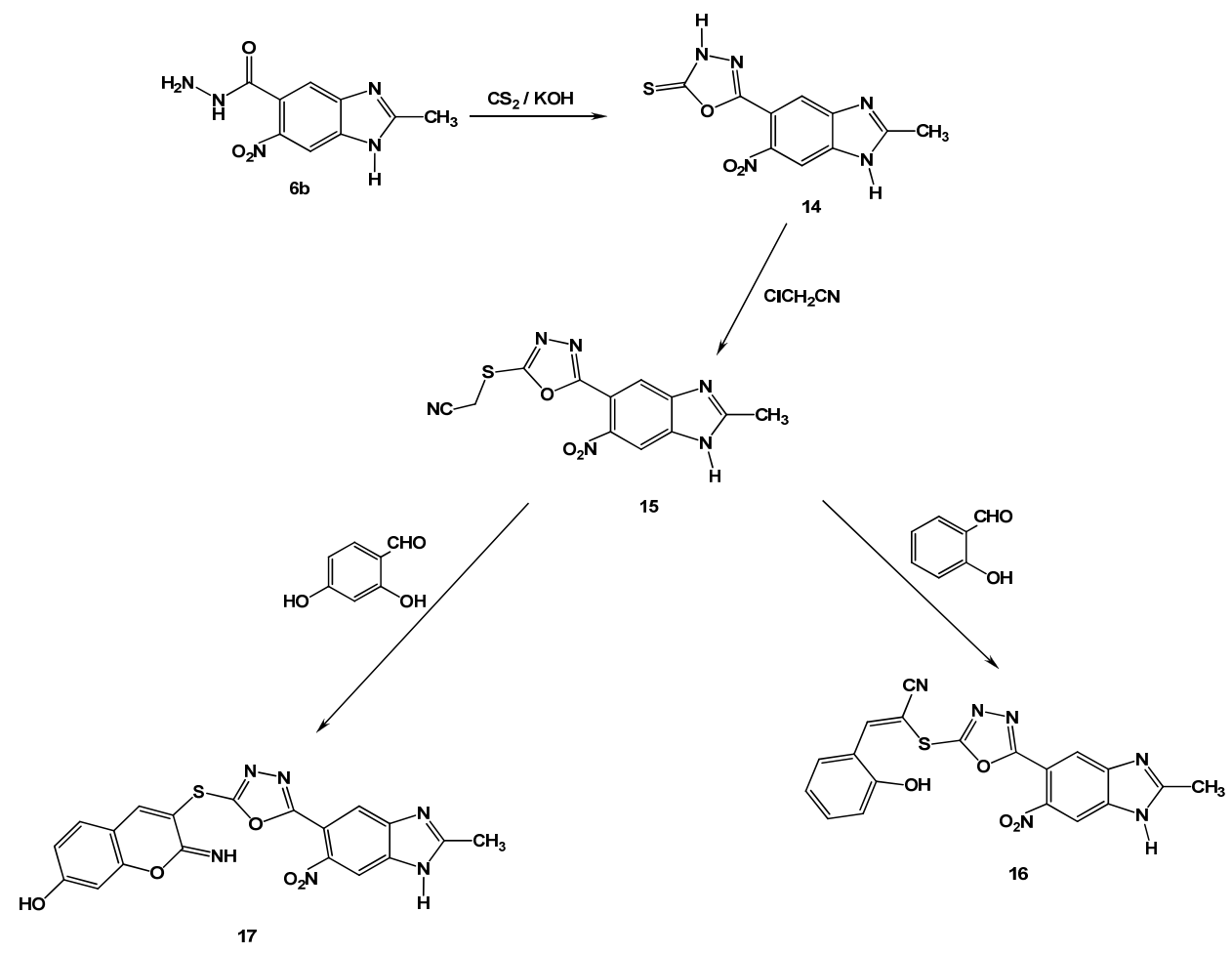

Scheme 4

an atmosphere of $5 \% \mathrm{CO}_{2}$ at $37^{\circ} \mathrm{C}$. After $24 \mathrm{~h}, 100 \mu \mathrm{L}$ of culture media and $2 \mu \mathrm{L}$ of the compound in DMSO were added to each well in duplicate, and the plates were incubated an additional $72 \mathrm{~h}$ at $37{ }^{\circ} \mathrm{C}$. There was no effect on the growth of cells compared to that of cells in culture media alone at this DMSO concentration. Compounds, along with mitomycin-C as a positive control were evaluated at final concentrations ranging from 0.001 to $50 \mu \mathrm{M}$.

After the $72 \mathrm{~h}$ incubation, the culture media was removed from each well, and $200 \mu \mathrm{L}$ of fresh media and $20 \mu \mathrm{L}$ of Alamar Blue reagent were added, followed by additional $6 \mathrm{~h}$ incubation. Cell viability was detected by fluorescent intensity using a Beckman Coulter DTX880 plate reader with excitation at $530 \mathrm{~nm}$ and emission at $590 \mathrm{~nm}$. The fluorescence data obtained from the cytotoxicity studies was used to calculate the percent growth according to the following equation (1):

$\%$ Growth $=100 *\left(F_{\text {test }}-F_{\text {time } 0}\right) /\left(F_{\text {ctrl }}-F_{\text {time } 0}\right)$

Where Mean $F_{\text {time0 }}=$ the averaged measured fluorescent intensities of Alamar Blue reagent at the time just before the exposure of the cells to the test substance; Mean $F_{\text {test }}=$ the averaged measured fluorescent intensities of Alamar Blue reagent after $72 \mathrm{~h}$ exposure of the cells to the test substance at a particular concentration; Mean $\mathrm{F}_{\mathrm{crtl}}=$ the averaged measured fluorescent intensities of Alamar Blue reagent after $72 \mathrm{~h}$ exposure of the cells to the vehicle without the test substance.

The $\mathrm{IC}_{50}$, the compound concentration for which the growth of treated cells from time 0 was only $50 \%$ as much as the vehicle-control was determined by non-linear regression fitting the data to equation (2):

$\mathrm{y}=\operatorname{Min}+(\operatorname{Max}-\operatorname{Min}) /\left(1+10^{\wedge}\left(\left(\mathrm{x}-\log \mathrm{IC}_{50}\right)^{*} \mathrm{n}\right)\right)$

Where $\mathrm{Min}=$ the minimum response plateau ( $0 \%$ Growth); $\mathrm{Max}=$ the maximum response plateau (100\% Growth); $\mathrm{y}=\%$ Growth at each test compound concentration; $n$ is a fitted parameter (the Hill slope coefficient).

\subsection{Instrumentation}

Melting points were taken on a capillary melting point apparatus and are uncorrected. ${ }^{1} \mathrm{H}$ and ${ }^{13} \mathrm{C}$ NMR spectra were recorded using Jeol EX-200 MHZ, $270 \mathrm{MHz}$ and $500 \mathrm{MHz}$ NMR spectrometers with $\mathrm{Me}_{4} \mathrm{Si}$ as an internal standard. Chemical shifts are reported in parts per million (ppm) from the tetramethylsilane resonance in the indicated solvent. Coupling constants are reported in Hertz (Hz), spectral splitting partners are designed as follow: singlet $(\mathrm{s})$; $\operatorname{doublet}(\mathrm{d})$; triplet $(\mathrm{t})$; multiplet $(\mathrm{m})$. Mass spectra were obtained with a Schimadzu GCS-QP $1000 \mathrm{EX}$ spectrometer at $70 \mathrm{ev}$. The IR spectra were recorded with a Philips Infracord Spectro-photometer Model PU9712 in KBr discs. Elemental analyses were performed at the Microanalytical Laboratory of the National Research Centre.

\section{Results and Discussion}

\subsection{Chemistry}

2-Methyl-1H-benzimidazole-5-carboxylic acid, 1, was prepared from 3,4-diaminobenzoic acid with acetic acid in hydrochloric acid according to Philips' method [19,20]. Treatment of compound $\mathbf{1}$ with ethanol and sulfuric acid afforded the ester $\mathbf{2}$ [21] which was nitrated to yield the 6(5)nitro derivative 3 [22] in which the nitro group was reduced using ferrous sulfate and hydrochloric acid to yield the 6(5)amino hydrochloride derivative 4 . The ortho position of the nitro or amino group vis-à-vis the ester group was proved by ${ }^{1} \mathrm{H}-\mathrm{NMR}$ as it did not show any meta coupling when the singlets corresponding to $\mathrm{H}_{4}$ and $\mathrm{H}_{7}$ were expanded.

Hydrolysis of the ester group of $\mathbf{3}$ was accomplished by refluxing in $10 \%$ sodium hydroxide to afford 5(6)-carboxylic acid derivative (5). The acid hydrazides $\mathbf{6}(\mathbf{a}, \mathbf{b})$ were formed by the reaction of the esters $\mathbf{2}$ or $\mathbf{3}$ with hydrazine hydrate. (Scheme 1).

The formation of a dihydrooxadiazole-2-thione ring at the 5(6) position of 2-methylbenzimidazole was achieved by the 
reaction of the hydrazides $\mathbf{6 a}$ [23] or $\mathbf{6 b}$ with carbon disulfide in potassium hydroxide to produce compounds $\mathbf{7}$ and $\mathbf{1 4}$ respectively. Sulfonylation took place when compound $\mathbf{7}$ reacted with methanesulfonyl chloride or 2-nitrobenzene esulfonyl chloride to obtain the thiosulfonothioate derivatives $\mathbf{8}$ and $\mathbf{9}$ respectively (Scheme 2). Reaction of chloroacetonitrile or 2-chloromethylbenzimidazole in pyridine to produce the 1,3,4-oxadiazole-2-thio derivatives $\mathbf{1 0}$ and $\mathbf{1 1}$, respectively. Stirring compound $\mathbf{7}$ with dibromoethane or diiodomethane in a molar ratio of 2:1 with anhydrous potassium carbonate in DMF yielded the bis compounds 12 and 13, respectively, (Scheme 3).

Similarly compound $\mathbf{1 4}$ reacted with chloroacetonitrile to produce the thioacetonitrile derivative, $\mathbf{1 5}$, which led to the aldol condensation products 16 upon it's reaction with salicylaldehyde. The iminopyran $\mathbf{1 7}$ resulted from the condensation of $\mathbf{1 5}$ with 2,4-dihydroxybenzaldehyde with subsequent addition of the $\mathrm{OH}$ on cyano group (Scheme 4).

Dehydrochlorination reaction of compounds $\mathbf{7}$ and $\mathbf{1 4}$ took place selectively on the thiol group of oxadiazole moiety by using equimolar reagents which was proved from the presence of NH of benzimidazole moiety as revealed from the IR and the ${ }^{1} \mathrm{H}$-NMR spectra of the products.

\subsection{The cytotoxicity}

The cytotoxicity of synthesized compounds and Mitomycin C was tested using the AlamarBlue assay [10] in breast cancer cel line MCF-7 and lung cancer cell line A549 (Table 1). Compound 1 did not show cytotoxity at the highest concentration examined $(100 \mu \mathrm{M})$ against both cell lines, whereas its ethyl ester derivative (2) was cytotoxic against MCF-7 ( IC $_{50}=62 \mu \mathrm{M}$ ). Compounds 3, 5, $6(\mathbf{a}, \mathbf{b})$ did not exhibit cytotoxity. Most of the compounds bearing the 5-thio-1,3,4-oxadiazol-2-yl group at the 5 th position of the benzimidazole ring have moderate growth inhibitory effects as compounds $7\left(\mathrm{IC}_{50}=21 \mu \mathrm{M}\right.$ and $\left.24 \mu \mathrm{M}\right), \mathbf{1 1}\left(\mathrm{IC}_{50}=26 \mu \mathrm{M}\right.$ and 21 $\mu \mathrm{M}), 12\left(\mathrm{IC}_{50}=19 \mu \mathrm{M}\right.$ and $\left.22 \mu \mathrm{M}\right), \mathbf{1 3}\left(\mathrm{IC}_{50}=37 \mu \mathrm{M}\right.$ and $\left.64 \mu \mathrm{M}\right)$, compounds 15 and $17\left(\mathrm{IC}_{50}=48 \mu \mathrm{M}\right.$ and $\left.24 \mu \mathrm{M}\right)$ and $16\left(\mathrm{IC}_{50}=\right.$ $20 \mu \mathrm{M}$ and $24 \mu \mathrm{M}$ ) against both MCF-7 and A549 cell lines respectively. Interestingly compound 9 exhibited potent cytotoxic effect against the two cell lines $\left(\mathrm{IC}_{50}=1.2 \mu \mathrm{M}\right.$ and $1.9 \mu \mathrm{M}$ ). However some exceptions (e.g. inactive compounds 8, 10 and 14) were noted.

Table 1. Cytotoxicity of the synthesized compounds against MCF-7 and A549 cell lines using the AlamarBlue assay [10].

\begin{tabular}{ccc}
\hline Compound & IC $_{\mathbf{5 0}}$ for MCF-7 Cells $(\boldsymbol{\mu M})$ & IC $_{\mathbf{5 0}}$ for A549 cells $(\boldsymbol{\mu M})$ \\
\hline 1 & $>100$ & $>100$ \\
2 & $62 \pm 18$ & $>100$ \\
3 & $>100$ & $>100$ \\
4 & $\mathrm{Nd}$ a & $>100$ \\
5 & $>100$ & $>100$ \\
$6 \mathrm{a}$ & $>100$ & $>100$ \\
$6 \mathrm{~b}$ & $>100$ & $24 \pm 5$ \\
7 & $21 \pm 3$ & $>100$ \\
8 & $>100$ & $1.9 \pm 0.1$ \\
9 & $1.2 \pm 0.1$ & $>100$ \\
10 & $>100$ & $21 \pm 3$ \\
11 & $26 \pm 5$ & $22 \pm 2$ \\
12 & $19 \pm 3$ & $64 \pm 16$ \\
13 & $37 \pm 8$ & $>100$ \\
14 & $>100$ & $24 \pm 3$ \\
15 & $48 \pm 28$ & $24 \pm 7$ \\
16 & $20 \pm 0.1$ & $24 \pm 3$ \\
17 & $48 \pm 2.8$ & $0.4 \pm 0.1$ \\
Mitomycin-C & $0.2 \pm 0.07$ &
\end{tabular}

On the basis of above screening, esterification of 2-methyl$1 H$-benzimidazole-5-carboxylic acid, $\mathbf{1}$, gave compound $\mathbf{2}$ of moderate cytotoxic effect, whereas nitration of compound 2 to form 3 reduced the cytotoxicity. Formation of the 5-(5-thio- 1,3,4-oxadiazol-2-yl) group led to an increase in the growth inhibitory effects on these two cell lines, where compound 9 showed potent activity. Whereas, compounds 7, 11-13, and 1517 showed moderate activity. The activity of these compounds is relatively insensitive to the nature of the 1,3,4-oxadiazole-2thio substituent; however, some exceptions (e.g., inactive compounds $8,10,14$ ) were found.

In conclusion, nitration of ethyl 2-methyl-1Hbenzimidazole-5-carboxylate took place selectively at position6. Oxadiazole-2-thione ring at the $5(6)$ position of 2 methylbenzimidazole was performed by the reaction of the hydrazides $(\mathbf{6 a}, \mathbf{b})$ with carbon disulfide. Dehydrochlorination and sulphonation reactions of compounds $\mathbf{7}$ and $\mathbf{1 4}$ took place selectively on the thiol group of oxadiazole moiety. The incorporation of 1,3,4-oxadiazole ring carrying 2-nitrophenyl group in its side chain to 2 -methyl- $1 H$-benzimidazole into the 5(6)-position was successful to increase the cytotoxic effect of the starting material. The reason of this may be the lipophilicity of the phenyl group together with the influence of the nitro group as a hydrogen bond acceptor.

\section{Acknowledgements}

We thank the US-Egypt Joint Science and Technology Board Fund, Administered through the USDA (BI09-002-015)

\section{References}

[1]. Boiani, M.; Gonzalez, M. Mini-Rev. Med. Chem. 2005, 5, 409.

[2]. Hori, A.; Imaeda, Y.; Kubo, K.; Kusaka, M. Cancer Lett. 2002, 183, 53.

[3]. Abdel-Mohsen H. T.; Ragab F. A. F.; Ramla M. M.; Diwani H. I. Eur. J. Med. Chem, 2010, 45, 2336-2344.

[4]. Velaparthi U.; Liu P.; Balasubramanian B.; Carboni J.; Attar R. Gottardis M.; Li A.; Greer A.; Zoeckler M.; Wittman M. D.; Vyas D. Bioorg. Med. Chem. Lett. 2007, 17, 3072-3076.

[5]. Pagano M. A.; Andrzejewska M.; Ruzzene M.; Sarno S.; Cesaro L.; Bain J.; Elliott M.; Meggio F.; Kazimierczuk Z.; Pinna L.A. J. Med. Chem. 2004, 47, 6239-6247.

[6]. Pagano M. A.; Meggio F.; Ruzzene M.; Andrzejewska M.; Kazimierczuk Z.; Pinna L. A. Biochem. Biophys. Res. Commun. 2004, 321, 1040-1044.

[7]. Neff D. K.; Lee-Dutra A.; Blevitt J. M.; Axe F. U.; Hack M. D.; Buma J. C. Rynberg R; Brunmark A.; Karlsson L.; Breitenbucher G. Bioorg. Med. Chem. Lett. 2007, 17, 6467-6471.

[8]. Arienti K. L.; Brunmark A.; Axe F. U.; McClure K.; Lee A.; Blevitt J.; Neff D. K.; Huang L.; Crawford S.; Pandit C. R.; Karlsson L.; Breitenbucher J. G. J. Med. Chem. 2005, 48, 1873-1885.

[9]. Hajduk J. P.; Boyd S.; Nettesheim D.; Nienaber V.; Severin J.; Smith R.; Davidson D.; Rockway T.; Fesik S. W. J. Med. Chem. 2000, 43, 38623866.

[10]. Kumar D.; Jacob M. R.; Reynolds M. B.; Kerwin S. M. Bioorg. Med. Chem. 2002, $10,3997-4004$

[11]. Aboraia A. S.; Abdel-Rahman H. M.; Mahfouz N. M.; EL-Gendy M. A., Bioorg. Med. Chem. 2006, 14, 1236-1246.

[12]. El Naem Sh. I.; El-Nzhawy A. O.; El-Diwani H .I.; Abdel Hamid A. O. Arch Pharm. Pharm. Med. Chem. 2003, 1, 7-17.

[13]. Ramla M. M.; Omar M. A.; Tokuda H.; El-Diwani H. I. Bioorg. Med. Chem. 2007, 15, 6489-6496.

[14]. Ramla M. M.; Omar M. A.; EL-Khamry A. M. M.; El-Diwani H. I. Bioorg Med. Chem. 2006, 14, 7324-7332.

[15]. Rostom S. A. F.; Shalaby M. A.; El-Demellawy M. A. Eur. J. Med. Chem 2003, 38, 959-974.

[16]. Loetchutinat C.; Chau F.; Mankhetkorn S. Chem. Pharm. Bull. 2003, 51, 728-730.

[17]. Kumar D.; Sundaree S.; Johnson E. 0.; Shah K. Bioorg. Med. Chem. Lett. 2009, 19, 4492-4494

[18]. Guimaraes C. R .W.; Boger D. L.; Jorgensen W .L. J. Am. Chem. Soc. 2005, 127, $17377-17384$.

[19]. Phillips A. M. J. Chem. Soc. 1928, 2393-2399.

[20]. Yamasaki N.; Imoto T.; Murai Y.; Hiramura T.; Oku T.; Sawada K. PCT Int. Appl. WO 9724334: Chem. Abst. 127 (1997) 135799.

[21]. Blackburn W.; Danzig M.; Hubinger H.; Soisson D.; Schultz H. P., J. Org Chem. 1961, 26 (8), 2805-2809.

[22]. Galal S. A.; Hegab K. H.; Kassab A. S.; Rodriguez M. L.; Kerwin S. M.; ElKhamry A. A.; El Diwani H. I. Eur. J. Med. Chem. 2009, 44,1500-1508.

[23]. Labouta I. M.; Hassan A. M. M.; Aboulwafa 0. M.; Kader O.; Monatsh. Chem. 1989, 120 (6-7), 571-574. 